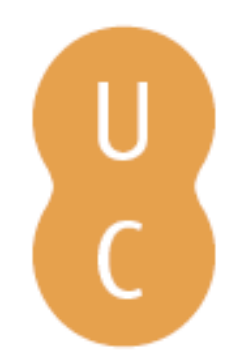

\title{
pombalina
}

\section{A poética da alegoria e o barroco}
Autor(es):
Silva, Vítor Manuel Aguiar e
Publicado por: Imprensa da Universidade de Coimbra; Ediciones Universidad
URL
persistente:
URI:http://hdl.handle.net/10316.2/31508
DOI:
DOI:http://dx.doi.org/10.14195/978-989-26-0245-5_5

Accessed : $\quad$ 26-Apr-2023 02:07:22

A navegação consulta e descarregamento dos títulos inseridos nas Bibliotecas Digitais UC Digitalis, UC Pombalina e UC Impactum, pressupõem a aceitação plena e sem reservas dos Termos e Condições de Uso destas Bibliotecas Digitais, disponíveis em https://digitalis.uc.pt/pt-pt/termos.

Conforme exposto nos referidos Termos e Condições de Uso, o descarregamento de títulos de acesso restrito requer uma licença válida de autorização devendo o utilizador aceder ao(s) documento(s) a partir de um endereço de IP da instituição detentora da supramencionada licença.

Ao utilizador é apenas permitido o descarregamento para uso pessoal, pelo que o emprego do(s) título(s) descarregado(s) para outro fim, designadamente comercial, carece de autorização do respetivo autor ou editor da obra.

Na medida em que todas as obras da UC Digitalis se encontram protegidas pelo Código do Direito de Autor e Direitos Conexos e demais legislação aplicável, toda a cópia, parcial ou total, deste documento, nos casos em que é legalmente admitida, deverá conter ou fazer-se acompanhar por este aviso.

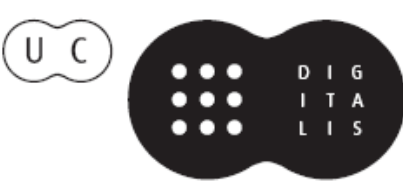


Marta Teixeira Anacleto

Sara Augusto

Zulmira Santos

Coordenação

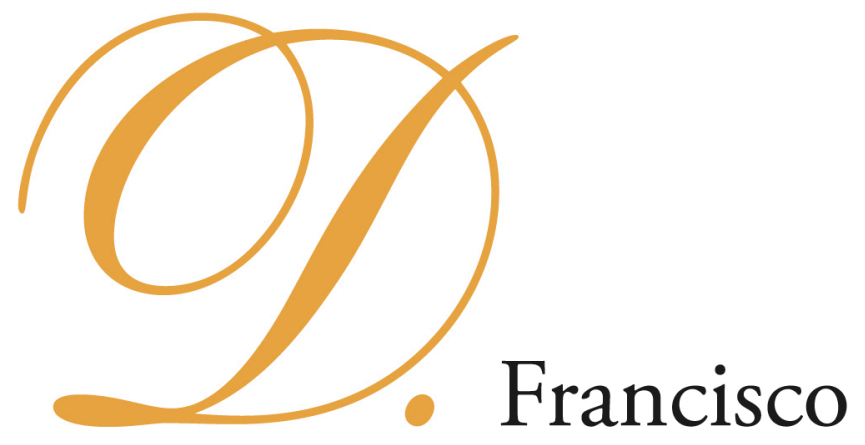

Manuel de Melo e o

Barroco Peninsular 


\title{
EDIĈ̣̃O
}

Imprensa da Universidade de Coimbra Ediciones Universidad Salamanca

\section{COORDENAÇÃo EDITORIAL}

Imprensa da Universidade de Coimbra

URL: http://www.uc.pt/imprensa_uc

Vendas online: http://www.livrariadaimprensa.com

\section{CONCEPÇÃO GRÁFICA}

António Barros

\section{REVISÃO TEXTO}

Sara Augusto

\author{
Pré-Impressão, Impressão e ACABamento \\ www.artipol.net
}

\section{IS B N}

978-989-26-0044-4 (Portugal)

978-84-7800-194-1 (Espanha)

DEPósito LEGAL

$311680 / 10$

OBRA PUBlicada COM O APOIO DE:

FCT Fundação para a Ciência e a Tecnologia

MINISTÉRIO DA CIÊNCIA, TECNOLOCIA E ENSINO SUPERIOR Portugal

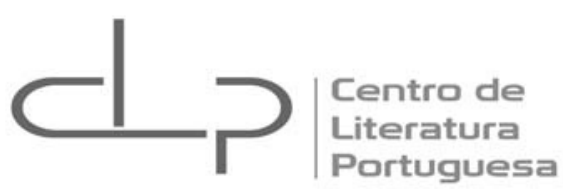

A presente publicação insere-se no Grupo "Poéticas" (coordenação de Marta Teixeira Anacleto) do Centro de Literatura Portuguesa, Unidade de I\&D financiada pela Fundação para a Ciência e a Tecnologia, ao abrigo do Programa Operacional Ciência e Inovação 2010.

(C) Agosto 2010

IMPRENSA DA UNIVERSIDADE DE COIMBRA

EDICIONES UNIVERSIDAD DE SALAMANCA 
Marta Teixeira Anacleto

Sara Augusto

Zulmira Santos

Coordenação

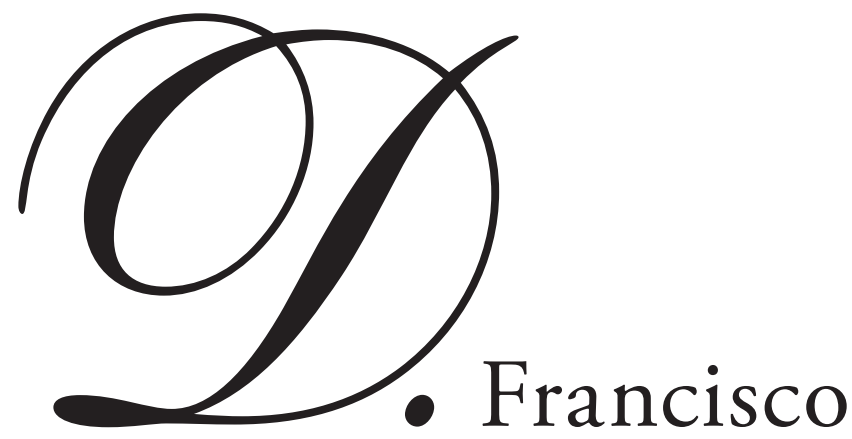

Manuel de Melo e o Barroco Peninsular

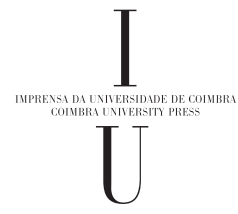


PARTE II

POÉtICAS DO BARROCO 


\section{Vítor Manuel Aguiar e Silva \\ Universidade do Minho}

\section{A POÉTICA DA ALEGORIA E O BARROCO}

\section{1.}

Quando comecei a preparar esta conferência, correspondendo à gentileza e à generosidade do convite que me foi dirigido pela Doutora Marta Teixeira Anacleto, minha antiga Aluna, cuja inteligência, finura e elegância de espírito muito estimo e admiro, pensei repetidamente, às vezes de modo obsidiante, em ensaios que li há alguns anos: «Adieu au Baroque?» de Jean Rousset, L'adieu au baroque de Daniel Klébaner e Dernier regard sur le Baroque também de Jean Rousset ${ }^{1}$.

Porquê rememorar assim estes ensaios? Sob a persona canonicamente discreta e austera do investigador universitário escondem-se emoçóes, memórias, sonhos, desejos e frustrações, quase sempre disciplinados, senão reprimidos, pelas convençóes e pelas bienséances do discurso académico e da instituição que o legitima e consagra. $\mathrm{O}$ adeus ao Barroco ... Como não sentir agora a nostalgia do fascínio de uma aventura intelectual empreendida há meio século, no tempo ainda solar da redescoberta maravilhada de uma arte e de uma poesia secularmente desvalorizadas e mesmo desprezadas por motivos de ordem religiosa, ideológica e estética? E como ocultar agora algumas dúvidas sobre as raízes e as razóes de um enamoramento antigo e algumas suspeitas incómodas sobre a congruência intrínseca e extrínseca de um conceito estético e estilístico-periodológico que foi tão ávida, trivializadora e frivolamente incorporado e exibido pelo Kitsch moderno e pós-moderno?

Como Daniel Klébaner, direi que «je garde simultanément du baroque une impression de fascination et de fatigue, d'enthousiasme mêlé de lassitude, une sorte de tristesse sans cause au coeur de la jubilation la plus haute» (p. 7), demarcando-me, porém, do que o autor exprime nesta última cláusula.

Esta restrição explica-se porque, na minha memória de estudioso e investigador da poesia lírica portuguesa da segunda metade do século XVI e do século XVII, o Maneirismo

\footnotetext{
${ }^{1} \mathrm{O}$ primeiro ensaio de Jean Rousset está coligido no seu volume L'intérieur et l'extérieur. Paris: Librairie José Corti,1968, pp. 239-245. O ensaio de Daniel Klébaner (Paris: Gallimard, 1979) retoma o título do ensaio de Jean Rousset, sem a interrogação. O segundo ensaio de Jean Rousset, primeiro publicado no no 105 (1997) da revista Littérature, abre o volume do autor com o mesmo título: Dernier regard sur le Baroque. Paris: José Corti, 1998.
} 
se entranhou e fixou como um fascínio sem hiatos nem ocasos e como uma interpelação permanente, sobretudo graças ao génio de Camóes; porque a poesia barroca portuguesa, com raras excepçóes, não tem densidade semântica, não tem fundura antropológica nem fulgor estilístico-formal; talvez porque eu, no mais secreto da minha sensibilidade e da minha inteligência, tenha permanecido sempre fiel a um certo ideal trans-histórico de intelectualismo estético, ou de classicismo, que hauri em anos juvenis na leitura de Baudelaire, de Mallarmé e sobretudo de Paul Valéry e que reencontro, só na aparência contraditoriamente, no meu deslumbrado interesse pelo fantástico.

Por outro lado, a melancolia do último olhar, não no sentido de olhar mais recente, mais actualizado e mais esclarecido, mas no sentido temporalmente definitivo de "último». O último olhar que propóe ou impóe uma paragem, um termo e o silêncio ulterior. "Adeus ao Barroco», «último olhar sobre o Barroco»... Quase quarenta anos depois da escrita da minha tese de doutoramento, os olhos que lançarão este último olhar são já outros: viram muita mudança e muita metamorfose, contemplaram novos céus e novas estrelas, para me apropriar de um tópico camoniano, e iluminaram-se com as análises e as reflexóes sobre o Barroco de Walter Benjamin - como eu lamento a ausência de Benjamin da minha tese de doutoramento ... -, de José António Maravall, de Giles Deleuze, de Christine Buci-Glucksmann e de muitos outros estudiosos, dentre os quais quero justamente mencionar Fernando Rodríguez de la Flor.

Se a poalha de ouro do Barroco poético se me começou a velar ainda durante o próprio processo de escrita da minha dissertaçáo doutoral e se me foi tornando progressivamente cendrada com o decurso dos anos, a cinza do tempo acendrou, assim o espero, o meu entendimento do Barroco em geral. Paradoxos? Equívocas agudezas? Foi o próprio Baltasar Gracián, mestre sem igual da subtilitas intelligendi, quem ensinou que, na e pela linguagem, o engenho pode dissolver a polaridade do gosto e do juízo ${ }^{2}$. É irremediável, porém, a melancolia do adeus, a melancolia do último olhar...

A distinção terminológica e conceptual, hoje largamente aceite e praticada, entre alegoria e alegorese, é importante para a compreensão dos fenómenos retóricos e hermenêuticos tradicionalmente designados de modo sincrético pela palavra alegoria. $\mathrm{O}$ termo alegoria inscreve-se no âmbito da retórica e designa portanto um fenómeno de expressão, de produção de um determinado efeito verbal, podendo manifestar-se num segmento de um texto ou caracterizar toda a estrutura formal e semântica de um texto; o termo alegorese inscreve-se no âmbito da hermenêutica e designa um determinado modo e uma determinada técnica de interpretaçáo de uma parte de um texto ou de um texto na sua totalidade ${ }^{3}$.

\footnotetext{
${ }^{2}$ Baltasar Gracián, El Criticón. Edición de Santos Alonso.Madrid: Cátedra, 2001², p. 69.Veja-se Klaus Heger, Baltasar Gracián. Estilo lingüistico y doctrina de valores. Zaragoza: Institución «Fernando el Católico», 1982, p. 186.

3 Paul de Man atribuiu ao termo alegorese um significado diferente, que não colheu aceitação: «The relationship between the proper and the literal meaning of the allegory, wich can be called 'allegoreme' and 'allegoresis' respectively (as one distinguishes between 'noeme' and 'noesis'), is not merely a relationship of non-
} 
Esta distinção suscita um problema complexo: saber se a alegorese só é possível e legítima se existir no texto uma alegoria ou uma sequência de alegorias ou se a alegorese se pode construir e desenvolver independentemente de tal pressuposto. No fundo, reverte-se a um dos problemas cruciais de toda a hermenêutica: a relação entre a intenção do autor e a interpretação do leitor.

A extraordinária fortuna da alegorese - sem a utilização deste termo, pois que ele é relativamente recente - teve o seu início, na Grécia antiga, entre os séculos VI e V a.C., quando ocorreu uma profunda transformaçáo no modo de ler, comentar e interpretar os textos dos poetas, sobretudo dos poetas maiores como Homero e Hesíodo. Perante os ataques virulentos de Xenófanes de Cólofon (sécs.VI-V a.C.) aos poemas homéricos, cujas imoralidades punham em causa a função educativa atribuída a estes poemas - «Quanto há de vergonhoso e censurável, /tudo isso atribuíram aos deuses Homero /e Hesíodo: roubos, adultérios, mentiras», lê-se num dos fragmentos que se conservam de Xenófanes - ${ }^{4}$, gerouse um movimento de reacção que ensinava a ler e a interpretar de outro modo, em consonância com os ideais e os valores da paideia grega, os textos denunciados como imorais. Segundo uma tradição tardia, recolhida por um escólio de Porfírio (séc. III d.C.) sobre o episódio da batalha dos deuses no canto XX da Ilíada ${ }^{5}$, terá sido Teágenes, da cidade de Régio, na Magna Grécia, o primeiro comentador de Homero que, no último quartel de século VI a.C., expôs a doutrina segundo a qual era necessário ler e entender outros significados sob aqueles que as palavras homéricas literalmente transmitiam. A alegorese de Teágenes propunha ler os mitos homéricos como ficçóes que encobriam verdades cosmológicas, físicas e morais. No século V a.C., outros autores, como Metrodoro de Lâmpsaco, discípulo de Anaxágoras, propuseram similares explicaçóes para os deuses e para os heróis de Homero, resgatando assim a Ilíada e a Odisseia das acusaçóes que sobre elas recaíam e que condenavam a sua permanência como pilares da educação grega. A orientação alegorética na leitura e na interpretação dos poemas homéricos foi prosseguida por autores como o sofista e cínico Antístenes, que terá sido o primeiro crítico a estabelecer a distinção entre «opinião» e «verdade» nos poemas de Homero, embora,

coincidence. The semantic dissonance goes further» (Paul de Man, Allegories of reading. New HavenLondon:Yale University Press, 1979, p. 74).

${ }^{4}$ Cf. Maria Helena da Rocha Pereira (org. e trad.), Hélade. Antologia da cultura grega. Porto: Ediçóes Asa, $2003^{8}$, p. 149.

${ }^{5}$ Sobre os ataques de Xenófanes e as propostas de interpretação alegórica dos poemas homéricos, desde Teágenes de Régio até aos comentadores e críticos estóicos e neoplatónicos vide em particular D.C. Feeney, The gods in epic. Poets and the classical tradition. Oxford: Clarendon Press, 1991, pp. 5 ss.; Robert Lamberton e John J. Keaney (eds.), Homer's ancient readers: The hermeneutics of greek epic's earliest exegetes. Princeton: Princeton University Press, 1992; Deborah L. Madsen, Rereading allegory. New York: St. Martin's Press, 1994, pp. 30 ss.; Luc Brisson, Introduction à la philosophie du mythe. I. Sauver les mythes. Paris: Vrin, 1996; Yun Lee Too, The idea of ancient literary criticism. Oxford: Clarendon Press, 1998, pp. 140 ss.; Andrew Ford, The origins of criticism. Literary culture and poetic theory in classical age. Princeton-Oxford: Princeton University Press, 2002, pp. 67 ss.; Robert Lamberton, "Language, text, and truth in ancient polytheist exegesis», in Jon Whitman (ed.), Interpretation and allegory. Antiquity to the modern period. Boston-Leiden: Brill, 2003; Luc Brisson, "L"allégorie" comme interprétation des mythes, de l'Antiquité à la Renaissance», in Brigitte Pérez-Jean e Patricia EichelLojkine (eds.), L'allégorie de l'Antiquité à la Renaissance. Paris: Honoré Champion, 2004. 
segundo Rudolfo Pfeiffer, os sofistas não tenham sido propriamente alegoristas ${ }^{6}$, e sobretudo, ao longo do período helenístico, pelos estóicos e neoplatónicos.

Os defensores dos poemas homéricos e hesiódicos advogavam que, sob o sensus litteralis ou o sensus grammaticus daqueles textos, era necessário procurar e apreender a hyponoia, isto é, o significado que se presumia estar escondido sob a forma patente do texto. Tratava-se, portanto, de desvelar o sentido oculto de partes de um texto ou de um texto na sua totalidade, propondo interpretaçóes que modificavam e apagavam o sentido «vergonhoso e censurável» transmitido pelo sensus litteralis. É a primeira defesa da poesia na história da cultura ocidental.

Platão revela-se refractário à alegorese, pois na República (378d) condena aquelas narrativas homéricas que relatam acçóes imorais e pedagogicamente perniciosas dos deuses: «é coisa que não deve aceitar-se na cidade, quer essas histórias tenham sido inventadas com um significado profundo, quer não. É que quem é novo não é capaz de distinguir o que é alegórico do que o não é» ${ }^{7}$. Em rigor, o filósofo não discute os aspectos filosóficos e cognitivos da alegorese, pois que a póe de lado por motivos de ordem social e pedagógica (no fundo, Platão não cauciona a alegorese como defesa da poesia). No Fedro (229d-e), Sócrates, embora admita que as explicaçóes alegoréticas têm o seu atractivo, considera que são próprias de homens excessivamente engenhosos e que representam uma imaginosa e infindável tarefa, às vezes lançando mão de uma sabedoria um tanto grosseira.

No período helenístico, o termo hyponoia foi substituído progressivamente pelo termo allégoria, como Plutarco, polígrafo que viveu entre meados do século I e início do século II d.C., registou no seu opúsculo De audiendis poetis (19F), ao afirmar que alguns cometem violência contra as narrativas [os mitos] recorrendo "ao que noutro tempo se denominava hyponoiai e presentemente se denomina allégoriai». Se Demétrio de Faléron escreveu o seu tratado Sobre o Estilo (Perì hermèneias), como defendem alguns estudiosos, cerca de 270 a.C. ${ }^{8}$, terá sido ele o autor de que ficou o primeiro testemunho sobre o termo e o conceito de allégoria. Nos parágrafos 99, 100 e 101do seu tratado, Demétrio caracteriza a allégoria como algo de sublime e como um véu que recobre de mistério as palavras utilizadas - um véu que, ao ser retirado, multiplicará e fecundará as interpretaçôes, visto ser natural que não se preste atenção ao que é claro e evidente, «como a homens que se despojam do seu vestuário». Acrescenta Demétrio que "[p]or isso os mistérios são revelados sob forma alegórica, para causar estremecimento e temor, como se estivessem na escuridão e na noite. Com efeito, a alegoria também se parece com a escuridão e com a noite»?.

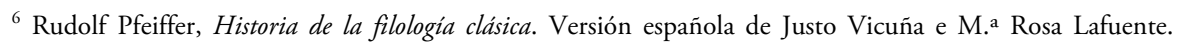
Madrid: Editorial Gredos, 1981, t. I, pp. 80-82.

${ }^{7}$ Platão, A República. Introdução, tradução e notas de Maria Helena da Rocha Pereira. Lisboa: Fundação Calouste Gulbenkian, ${ }^{5} 1987$, p. 90 . Como se esclarece adiante, o termo allēgoria não aparece em Platão.

${ }^{8}$ As opiniōes dos estudiosos e especialistas dividem-se não só quanto à data da composição da obra, que poderá ser mais tardia do que a indicada, mas também quanto à autoria da obra (cf. George A. Kennedy, «The evolution of a theory of artistic prose", in George A. Kennedy (ed.), The Cambridge history of literary criticism. Vol. 1. Classical Criticism. Cambridge: Cambridge University Press, 1989, p. 196).

9 Demétrio, Sobre el Estilo. Introducción, traducción y notas de José García López. Madrid: Editorial Gredos, 1979, p. 61. 
Tanto hyponoia como allégoria são substantivos que se inscrevem no campo semântico do conhecimento transmitido pelo discurso: hyponoia relaciona-se com o verbo hyponē, conjecturar, supor, conhecer por debaixo; allëgoria relaciona-se com o verbo allégoreō, composto pelo prefixo allos, outro, diferente, de outro modo, e o verbo agoreō, falar em público, falar na assembleia, ou seja, na agora ${ }^{10}$. A allēgoria é por conseguinte um discurso que dissimula e oculta os seus significados, náo coincidindo o significado que se patenteia, que se mostra publicamente, e a substância semântica que se esconde e que pode mesmo converter-se em ainigma, isto é, expressão obscura, equívoca e misteriosa. Plutarco, aliás, que era iniciado nos mistérios dionisíacos e que conhecia bem os mistérios egípcios, prefere o termo ainigma aos vocábulos hyponoia e allégoria ${ }^{11}$.

Quer dizer, os termos e os conceitos de hyponoia e de allégoria relevam originariamente de operaçóes de interpretação, de exegese, de hermenêutica e em especial de alegorese, embora as fronteiras destas operaçóes com as práticas retóricas e poiéticas, ou seja, de construção ou produção de textos, sejam fluidas e porosas, como demonstra o facto de o vocábulo hermēneia, que se tornou sinónimo de interpretação e de explicação textual, apresentar como significado primeiro e principal o acto de exprimir verbalmente o logos interior e, em particular, o acto de o exprimir oralmente ${ }^{12}$. Por conseguinte, hyponoia e allégoria, como operaçóes hermenêuticas e retóricas, são, numa perspectiva moderna, duas manifestaçóes ou faces de uma poética: por um lado, o intérprete, ouvinte ou leitor, desvela sob a letra do texto o(s) significado(s) oculto(s), profundo(s) e verdadeiro(s); por outro lado, o poiètēs, em geral com intencionalidade, subpóe ao sensus litteralis do texto um sensus spiritualis que representa sempre uma translação daquele.

A alegoria, como operação hermenêutica, corresponde à necessidade de renovar o sentido dos textos sobre os quais o tempo exerceu uma acção desfiguradora ou opacificante, envelhecendo e tornando ana-crónicos o seu léxico, a sua sintaxe e a sua semântica e obscurecendo as suas coordenadas referenciais e contextuais. A interpretação alegórica funda-se na liberdade e na criatividade do leitor/intérprete, que projecta no texto a sua exo-topia linguística e cultural, os seus valores, as suas crenças e os seus desejos ${ }^{13}$. A alegorese é sempre tendencialmente disseminadora de sentidos plurais e diversos e por isso, em todos os tempos, se desenvolveram esforços e se formularam propostas para estabilizar essa deriva alegorética, elaborando convenções que tornam a escrita alegorética

\footnotetext{
${ }^{10}$ Por outro lado, agora significa também o mercado, o espaço onde se vendem mercadorias, provisôes, e por isso alguns dos vocábulos derivados de agora, como o adjectivo agoraios, têm o significado de comum, baixo, trivial e mesmo grosseiro.

${ }^{11}$ Cf. Luc Brisson, Sauver les mythes, p. 84. Ainigma, como o adjectivo ainigmatōdès e o verbo ainittomai, deriva de ainos, narrativa ou expressão enigmática e ambígua que tem destinatários especiais (cf. Gregory Nagy, Pindar's Homer. The lyric possession of an epic past. Baltimore-London: The Johns Hopkins Press, 1990, p. 148).

${ }^{12}$ Jean Pépin, «L’herméneutique ancienne. Les mots et les idées», Poétique, 23 (1975), pp. 291-300.

${ }^{13}$ Sob este ponto de vista, como bem entendeu David Dawson, a alegorese é um relevante instrumento de poder simbólico: "Allegory is not so much about the meaning or lack of meaning in texts as it is a way of using texts and their meanings to situate oneself and one's community with respect to society and culture» (David Dawson, Allegorical readers and cultural revision in ancient Alexandria. Berkeley-Los Angeles-Oxford: Berkeley University Press, 1992, p. 236).
} 
- com efeitos correlativos na interpretação - numa escrita codificada, para retomar o título de uma obra de Georges Couton ${ }^{14}$.

$\mathrm{Na}$ época helenística, a alegorese fruiu de grande fortuna na Escola de Pérgamo, dotada de uma riquíssima biblioteca, na qual pontificaram pensadores e críticos estóicos, dentre os quais avultou Crates de Malos. Em contraposição, a Escola de Alexandria, graças sobretudo ao labor de Aristarco de Samotrácia (ca.217-ca.143 a.C.), cultivou um saber filológico que privilegiou o sensus grammaticus e o sensus historicus, com o objectivo de reconstituir as liçóes originais dos textos deteriorados e adulterados, de esclarecer os passos obliterados pelo tempo, os vocábulos caídos em desuso e as referências histórico-contextuais já esquecidas.

$\mathrm{Na}$ história da hermenêutica ocidental, Pérgamo e Alexandria representam os dois pólos de uma tensão contínua que atravessa os séculos, que esteve no cerne de grandes conflitos religiosos e de grandes dissensos filosófico-doutrinários, e que mantém uma actualidade vivíssima na hermenêutica em geral e, em particular, na hermenêutica literária: a tensão entre a hermenêutica material do texto, escrutinada com rigor filológico, e a hermenêutica alegorética, figural, metafórica e simbólica; a tensão entre a intenção do autor e a intenção do leitor; a tensão entre a conservação e a preservação do sentido originário da obra e a construçáo e o desvelamento de sentidos novos, que poderão não ter existido na consciência e na intenção do autor ${ }^{15}$.

Sem a lição filológica da Escola de Alexandria, os textos correriam o risco de ser adulterados e falsificados, com a adjunção de apócrifos, com alteraçóes espúrias, com lacunas, com deturpaçóes idiomáticas, com interpretaçóes fantasiosas que a hermenêutica material do texto não consente. Sem a lição da alegorese da Escola de Pérgamo, as perdas e as rupturas ou fracturas na cultura ocidental seriam incomensuráveis: os textos perderiam muito do seu potencial de plurissignificação, da sua capacidade de responderem a novas perguntas e de dialogarem com novos contextos e novos discursos; o diálogo entre a tradição greco-latina e a tradição cristã ter-se-ia tornado muito difícil e litigioso ${ }^{16}$; de

${ }^{14}$ Georges Couton, Écritures codées. Essais sur l'allégorie au XVII siècle. Paris: Aux Amateurs des Livres, 1990. A alegorese origina um dos problemas mais complexos com que se defronta a crítica literária, como Northrop Frye pôs em evidência: todo o comentário crítico, pela sua própria natureza, é tendencialmente alegorético e para não se tornar um moinho de alegorias, tem de postular que «[g]enuine allegory is a structural element in literature: it has to be there, and cannot be added by critical interpretation alone» (cf. Northrop Frye, Anatomy of criticism. New York: Atheneum, 1966 [1957], p. 54). Northrop Frye formula assim o princípio hermenêutico, que se me afigura fundamental, de que o significado textual tem de ser construído no diálogo entre a intentio operis, apurada na materialidade do texto, e a intentio lectoris.

${ }^{15}$ Foi Schleiermacher quem formulou o célebre princípio hermenêutico segundo o qual o intérprete deve compreender melhor o texto de um escritor do que este próprio (cf. Friedrich Schleiermacher, Herméneutique. Traduction et introduction de Marianna Simon. Genève: Éditions Labor et Fides, 1987, pp. 76, 114 e 120). Sobre esta material, veja-se Tonino Griffero et alii, Ciò che l'autore non sa. Ermeneutica, tradizione, critica. Milano: Guerini e Associati, 1988.

${ }^{16}$ Walter Benjamin escreveu que "[a] alegorese nunca teria surgido se a Igreja tivesse conseguido eliminar radicalmente os deuses da memória dos crentes» (Walter Benjamin, Origem do drama trágico alemão. Edição, apresentação e tradução de João Barrento. Lisboa: Assírio \& Alvim, 2004, p. 246). A afirmação de Benjamin é historicamente inexacta - a alegorese surgiu cerca de seis séculos antes de a Igreja se ter constituído -, mas é verdadeira no seu espírito: a alegorese manifestou-se e floriu sempre que o diálogo entre contextos culturais 
modo similar, o diálogo entre o Judaísmo e o Cristianismo, entre o Antigo Testamento e o Novo Testamento, teria sido muito mais árduo, conflituoso e talvez mesmo inviável ${ }^{17}$, náo teria sido possível criar muitas obras-primas da literatura e da arte europeias, desde a Divina Comédia e Os Lusíadas à Montanha mágica e ao Processo, desde a Primavera de Boticelli à Guernica de Picasso.

A Escola de Alexandria e a Escola de Pérgamo representam assim, na cultura helenística e, por herança, na cultura cristá dos primeiros séculos, as duas orientaçóes fundamentais de toda a hermenêutica: a interpretação segundo o sensus grammaticus e a interpretação segundo o sensus spiritualis. As duas orientaçóes podem extremar-se, convertendo-se dogmaticamente em ortodoxias, ou podem articular-se e interagir, como ocorreu, por exemplo, em Orígenes (séc. III d.C.), para quem o sentido primeiro, simples e insubstituível da Sagrada Escritura só pode ser edificado com «a carne do texto», isto é, com o sensus litteralis, com o sensus historicus, mas "o significado perfeito», isto é, completo, integral, segundo a lição de S. Paulo exposta em diversos passos das suas Cartas, só pode ser edificado segundo "a lei do espírito» ${ }^{18}$. A concepção literalista do sentido do texto salva "a carne» do texto, mas institui um quadro hermenêutico formular que restringe o sentido como refém do integumentum (a cobertura, a vestimenta) textual. Por isso, segundo Orígenes, o sentido histórico deve ser aprofundado, numa estratificação tripartida integrada, pelo sentido moral e pelo sentido espiritual (esta tripartição será depois desenvolvida no modelo exegético medieval dos quatro sentidos dos textos sagrados: o sentido literal, o sentido alegórico, o sentido moral e o sentido anagógico $)^{19}$.

diferentes ou antagónicos se tornou necessário, oportuno ou aconselhável, mesmo se esse diálogo tem como objectivo, implícito ou explícito, impor uma hegemonia, como ficou dito acima na nota (13). Sobre a importância da alegorese na sobrevivência dos deuses pagãos, veja-se a obra clássica de Jean Seznec, The survival of the pagan gods. Princeton: Princeton University Press, 1972 [ed. em francês, 1940]. A alegoria como género literário fortemente codificado restringe a liberdade da alegorese, porque orienta pormenorizadamente os caminhos da interpretaçáo.

${ }^{17}$ No diálogo entre o Judaísmo e o Cristianismo desempenhou papel fundamental a interpretação figural ou tipológica, segundo a qual doutrinas, personagens e eventos do Antigo Testamento prefiguram equivalentes elementos do Novo Testamento, no qual aqueles alcançam uma existência plena. O conceito de figura ou de tipo representa assim uma ponte entre duas comunidades religiosas e culturais. Sobre a interpretaçáo figural ou tipológica, veja-se o clássico estudo de Erich Auerbach, Figura. Madrid: Editorial Trotta, 1998 (a primeira publicação deste célebre estudo remonta a 1938). Veja-se ainda a excelente introdução, intitulada "Erich Auerbach: una poética de la historia», de José M. Cuesta Abad àquela traduçáo espanhola. Encontra-se informação actualizada sobre a interpretação figural no estudo de Paula Fredriksen, "Allegory and reading God's Book: Paul and Augustine on the destiny of Israel», in Jon Whitman (ed.), op. cit., pp. 125-149.

${ }^{18}$ A mais famosa e influente lição de S. Paulo encontra-se na 2. a Carta aos Coríntios, 3:4.6: «É por Cristo que temos tal confiança em Deus. Náo é que sejamos capazes por nós, de pensar alguma coisa, como de nós mesmos; não, a nossa capacidade vem de Deus. Ele é que nos fez capazes de sermos ministros de uma nova aliança, não da letra, mas do espírito; porque a letra mata, mas o espírito vivifica» (tradução da Bíblia Sagrada. Lisboa: Difusora Bíblica, $1986^{13}$, p. 1522).

${ }^{19}$ Sobre o modelo hermenêutico de Orígenes, vide José Domínguez Caparrós, Orígenes del discurso crítico. Teorias antiguas y medievales sobre la interpretación. Madrid: Editorial Gredos, 1993, pp. 143-157; Deborah L. Madsen, op. cit., pp. 48 ss.; David Dawson, «Plato's soul and the body of the text in Philo and Origen», in Jon Whitman (ed.), op. cit., pp. 89-107. Sobre o quadruplex sensus, veja-se Henri de Lubac, Exégèse médiévale: les quatre sens de l'Écriture. Paris: Le Cerf, 1993 [1959-64]. 
Em suma, a concepção alegorética do sentido do texto alarga e aprofunda a perspectiva hermenêutica, ao conduzir à busca do alieniloquium, do significado outro que se oculta sob o integumentum textual - "Allegoria est alieniloquium. Aliud enim sonat, et aliud intellegitur», segundo as palavras de Santo Isidoro de Sevilha $-^{20}$, mas se menosprezar ou esquecer a hermenêutica material do texto, gerará uma errância arbitrária de significados que acabará por destruir o próprio texto.

3.

Não vou esboçar, sequer, por inútil para o objectivo da presente análise, os percursos e as vicissitudes da alegoria e da alegorese desde Fílon de Alexandria e os Padres da Igreja até à Escolástica e a Dante, matéria minudente e rigorosamente examinada por Henri de Lubac na sua monumental obra já citada e por Jean Pépin numa obra igualmente notável ${ }^{21}$. Quero chamar a atenção, porém, para o facto de o conflito plurissecular entre a hermenêutica do sensus litteralis e a hermenêutica do sensus allegoricus ter conhecido uma virulência extrema na época do Humanismo e do Renascimento.

O neoplatonismo florentino, sob a influência de pensadores do neoplatonismo helenístico como Porfírio, Iâmblico e sobretudo Dionísio Areopagita, e sob o influxo dos mistérios egípcios e das tradiçóes herméticas, elaborou uma pia philosophia, uma docta religio, uma "teologia poética», em que a alegoria é uma operação poiética e hermenêutica innata e não illata, isto é, inscrita na natureza dos textos, dos mitos e do próprio cosmos e não inferida ou conjecturada através de um raciocínio ou de uma suposição mental. É célebre a carta "Prospera in fatum» de Marsilio Ficino endereçada a Laurentius Minor, ou seja, a Lorenzo di Pierfrancesco de’Medici, jovem primo de Lorenzo de’Medici, na qual descreve alegoreticamente a Venus-Humanitas, fazendo corresponder aos atributos mentais e físicos da deusa virtudes espirituais e morais de excelsa elevaçáo ${ }^{22}$.

A proliferação e a fantasia desenfreada das interpretações alegoréticas do neoplatonismo renascentista e de outras similares explicam a ironia devastadora com que Rabelais, no prólogo de Gargantua, se refere aos alegorizadores antigos e modernos - personificados estes últimos em Angelo Poliziano, que a todos os outros teria roubado -, os quais extraíram de poetas como Homero e como Ovídio as mais peregrinas invençóes alegóricas.

\footnotetext{
${ }^{20}$ San Isidoro de Sevilla, Etimologías. Edición bilingüe preparada por José Oroz Rete e Manuel-A. Marcos Casqueiro. Madrid: Biblioteca de Autores Cristianos, 1993², vol. I, p. 346.

${ }^{21}$ Jean Pépin, La tradition de l'allégorie de Philon d'Alexandrie à Dante: Études Historiques. Paris: Études Augustiniennes, 1987.

${ }^{22}$ Sobre esta alegorese de Marsilio Ficino, vide Luisa Rotondi Secchi Tarugi, «La ripresa del mito di Venere nel'400", in id. (a cura di), Il mito nel Rinascimento. Milano: Nuovi Orizzonti, 1993, pp. 410-411; Isabelle Pantin, «Ficin, l'allégorie et les lumineux secrets du monde», in Brigitte Pérez-Jean e Patricia Eichek-Lojkine (eds.), op. cit., pp. 544-545. A alegorese de Ficino foi utilizada por Gombrich na sua análise da Primavera de Boticelli (cf. Ernst Gombrich, Symbolic images. London: Phaidon Press, 1972, pp. 41-42).
} 
Um exemplo de raro equilíbrio entre filologia e alegorese encontra-se em Erasmo de Rotterdam, que investiu na edição e no estudo do Novo Testamento o seu sólido saber filológico e em particular o seu acurado conhecimento do latim e do grego - a sua edição em língua grega do Novo Testamento foi publicada em 1516 -, mas que escreve, no capítulo 2 do Enchiridion Militis Christiani, que «[a]ssim como a Sagrada Escritura produz pouco fruto se te deténs e te contentas com a letra, do mesmo modo a poesia de Homero e de Virgílio será de náo pequena utilidade se tiveres em conta que toda ela é alegórica [...]». E continua: «Dos intérpretes da Sagrada Escritura hás-de escolher todos aqueles que mais se afastam da letra. Tais são, por exemplo, depois de São Paulo, Orígenes, Santo Ambrósio, São Jerónimo, Santo Agostinho. Vejo que os mais modernos teólogos se apegam demasiado alegremente à letra e gastam as suas energias mais em subtilezas capciosas do que em iluminar o sentido oculto, como se São Paulo não tivesse dito que a nossa lei é a do espírito» ${ }^{23}$. A apologia erasmiana da leitura alegorética da Sagrada Escritura enraíza-se no magistério de São Paulo e de Santo Agostinho e da exegese bíblica medieval que, como ficou dito, interpreta passagens, personagens e episódios do Antigo Testamento como figuras ou como tipos, isto é, como profecias e como antecipaçóes do Novo Testamento. Como evidenciou Erich Auerbach, com a interpretaçáo figural o Antigo Testamento deixou de ser o livro da lei e da história de Israel e ganhou a dimensão universal que o Cristianismo proclamou e difundiu entre povos e culturas de origem e tradiçóes muito diversas. Repito: o sensus litteralis e a interpretação literalista circunscrevem e imobilizam os significados, no tempo e no espaço; o sensus allegoricus e a alegorese disseminam os significados, abrem horizontes dialógicos de ordem inter-étnica, intercultural e inter-histórica.

A formação teológica e filológica ensinava a Erasmo, porém, que a disseminação alegorética dos significados devia ter disciplina e limites, de modo a não transformar-se numa imensa teia de aranha frágil e inútil: no Ecclesiastes sive concionator evangelicus, obra dos seus últimos tempos de vida (1535), Erasmo afirma inequivocamente que nenhum elemento da doutrina cristã se pode fundamentar numa interpretação alegórica. No fundo, Erasmo aceita a doutrina de S. Tomás de Aquino segundo a qual o sentido literal é o fundamento dos outros sentidos ${ }^{24}$.

A rejeição da alegorese constituiu, como é sabido, um dos pilares da Reforma protestante, tanto luterana como calvinista. O princípio hermenêutico da sola Scriptura e o preceito correlato de cavete ab alegoriis - evitai as alegorias, desconfiai das alegorias -, formuladas por Lutero, conduziram as Igrejas e as comunidades reformadoras a uma interpretaçáo literalista e autónoma por parte de cada fiel do texto da Sagrada Escritura, porque a res, isto é, a Revelação é claríssima e por isso a Bíblia é intérprete de si mesma, sem ser necessária a auctoritas hermenêutica da hierarquia eclesial, nem os imaginosos artifícios das alegorias.

${ }^{23}$ Erasmo de Rotterdam, Enquiridion. Manual del caballero cristiano. Introducción, traducción y notas de Pedro Rodríguez Santidrián. Madrid: Biblioteca de Autores Cristianos, 1995, p. 73 e p. 76.

${ }^{24}$ Cf. Gerald L. Bruns, Hermeneutics ancient and modern. New Haven-London: Yale University Press, 1992, p. 141. 
$\mathrm{Na}$ tradição retórica latina, desde a Rhetorica ad Herennium até ao De Oratore e ao Orator de Cícero e à Institutio Oratoria de Quintiliano, a alegoria é caracterizada como sendo um tropo, cuja designação grega é traduzida por permutatio e por inuersio, constituído por uma série contínua de metáforas. Cícero caracteriza assim o tropo: «lam cum fluxerunt continuae plures tralationes [=translationes], alia plane fit ratio; itaque genus hoc Graeci appellant $\dot{\alpha} \lambda \lambda \eta \gamma o \rho i ́ \alpha v$, nomine recte, genere melius ille qui ista omnia tralationes uocat»(Orat., 94). E Quintiliano formula a seguinte definição:« $\alpha \lambda \lambda \eta \gamma o i^{\prime} \alpha v$ facit continua $\mu \varepsilon \tau \alpha \varphi \rho \alpha_{\alpha} »$ (Institutio oratoria, 9, 2, 46) ${ }^{25}$. Este entendimento ganhou secular e larga aceitação na retórica ocidental.

A alegoria é portanto um tropo que, tal como a metáfora e a comparação, se funda na analogia e na translação dos significados e que tem estreitas relaçóes com a ironia - lembre-se o termo latino inuersio -, a personificação e a prosopopeia, embora não se identifique com nenhuma destas figuras e apresente, em relação a todas elas, relevantes diferenças.

É particularmente elucidativa a análise comparativa da metáfora e da alegoria. A metáfora é uma figura de ordem microestrutural, ou seja, é delimitável num segmento preciso do discurso, modifica-se se houver alteração dos elementos formais, identifica-se de imediato e sem dificuldade e é interpretável em função de um contexto restrito. A alegoria é uma figura de ordem macroestrutural - não é delimitável num segmento preciso do discurso, permanece se houver alteração dos elementos formais, não é identificável de imediato e só é interpretável em função de um contexto alargado -, mas pode não consistir num fenómeno retórico verbal, pois pode fazer parte de um texto icónico-verbal, como o emblema, e pode ser constituída por um artefacto icónico não verbal, como um quadro de pintura que represente, por exemplo, o amor divino e o amor profano ou como uma estátua que represente a justiça.

A metáfora não pode deixar de ser lida e interpretada como metáfora, ao passo que a alegoria pode ser lida não alegoricamente. Quais as razôes que têm conduzido a ler a Ode I, 14, de Horácio - «Navio, novas ondas para o mar te levarão!/ Oh, que fazes? Ocupa resoluto o teu porto!» ${ }^{26}$, como uma alegoria do Estado e dos perigos que sobre ele impendem ? Eu posso ler a ode sem lhe conferir este sentido alegórico; posso atribuir-lhe, por exemplo, o sentido da condenação dos riscos e perigos das navegaçóes e o louvor implícito de uma vida tranquila. Aquele sentido alegórico da nave como representando o Estado, das ondas do pélago irado como representando os perigos políticos e bélicos, etc., deriva do comentário de Quintiliano (Institutio oratoria, 8, 6, 44), isto é, tem uma matriz metapoética, e procede de uma rede intertextual em cuja tessitura encontramos autores como Alceu, Teógnis, Cícero, etc.

\footnotetext{
${ }^{25}$ Sobre a história do termo «alegoria», vide em especial: Jon Withman, Allegory. The dynamics of an ancient and medieval technique. Cambridge, Mass.: Harvard University Press, 1987, "Appendix I. On the history of the term 'allegory'»; Jean-François Thomas, "Le mot latin allegoria», in Brigitte Pérez - Jean e Patricia Eichek-Loikine (eds.), op. cit., pp. 75-92.

${ }^{26}$ Horácio, Odes. Tradução de Pedro Braga Falcão. Lisboa: Livros Cotovia, 2008, p. 76.
} 
Por outro lado, como fenómeno retórico-verbal de ordem macroestrutural, a alegoria pode manifestar-se num enunciado, numa sequência de enunciados, em textos mais ou menos longos genologicamente configurados como a parábola, a fábula, o exemplo, o romance alegórico, o drama alegórico, etc ${ }^{27}$. A metáfora, como fenómeno retórico-verbal de ordem microestrutural, não detém similar capacidade expansiva, embora possa adquirila, ao converter-se em alegoria ${ }^{28}$.

A distinção medieval entre a allegoria in factis, que envolve res, factos, eventos e personagens históricos que são figuras, profecias ou prediçóes de outros factos, eventos e personagens, e a alegoria in verbis, construída discursivamente por imagens e metáforas, não tem correspondência no plano da metáfora ${ }^{29}$.

A metáfora, a não ser nos casos da metáfora lexicalizada e da catacrese, é criada e tem de ser interpretada como uma iluminação, como uma fulguração que desvela analogias ocultas, esquecidas, secretas e inéditas entre seres e objectos; a alegoria é uma construção que se dissemina no macrocontexto, em reiteraçóes, modulaçóes e desenvolvimentos múltiplos, que o intérprete tem de apreender e compreender utilizando a estratégia do «modelo cinegético», para utilizar uma engenhosa e elucidativa designação proposta por Terence Cave, isto é, recolhendo indícios, identificando pegadas e seguindo pistas textuais ${ }^{30}$.

5.

A alegoria pode dissimular astuciosamente e ocultar os seus significados, como no caso da chamada totta allegoria, que por isso se aproxima do aenigma, requerendo intérpretes iniciados em saberes especializados, que podem mesmo consistir em mistérios e tradiçóes de natureza religiosa e hermética. Nestes casos, a alegoria inscreve-se numa teologia do secreto e do segredo e, como bem observou Marc Fumaroli, o seu propósito é sacralizar o próprio discurso $^{31}$.

No imaginário pós-tridentino, Deus - um deus absconditus - criou o mundo como um omnipotente emblematista, povoando o céu e a terra de misteriosos objectos e sinais, de secretas figuras e representaçóes. Num universo assim hieroglificamente «escrito» e configurado, o próprio conceito de sentido literal carece de fundamento e legitimidade, pois a sua semântica é originariamente denegada no plano ontológico ${ }^{32}$.

\footnotetext{
${ }^{27}$ Muitos textos literários apresentam, como disse, uma estrutura alegórica genologicamente marcada, mas julgo inexacto subsumir todas as alegorias em géneros literários alegóricos, como propóe Carolyne van Dyke na sua valiosa obra The fiction of truth: Structures of meaning in narrative and dramatic allegory (Ithaca: Cornell University Press, 1985).

${ }^{28}$ Um fenómeno diferente é o da reiteração, ao longo de um texto, da mesma metáfora ou de metáforas inscritas no mesmo campo semântico.

${ }^{29} \mathrm{O}$ estudo clássico sobre esta distinção é o de Armand Strubel, "Allegoria in factis et allegoria in verbis", Poétique, 23 (1975), pp. 342-357.

${ }^{30}$ Cf. Terence Cave, Recognitions. A study in Poetics. Oxford: Clarendon Press, 1988, p. 251.

${ }^{31}$ Marc Fumaroli, Héros et orateurs. Genève: Droz, 1990, p. 316.

${ }^{32}$ Veja-se Patrick Labarthe, Baudelaire et la tradition de l'allégorie. Genève: Droz, 1999, pp. 17-18.
} 
No caso da chamada permixta apertis allegoria ${ }^{33}$, a própria alegoria proporciona elementos que orientam o leitor na sua compreensão e decifração. É o que sucede, por exemplo, com a chamada alegoria nominal, em que a onomástica das personagens indicia e desvela ab initio o significado alegórico dessas mesmas personagens e das narrativas onde figuram $^{34}$. Aliás, para guiar o leitor e o espectador na interpretação das alegorias, muitas delas oriundas da mitologia greco-latina, foram publicadas no século XVI diversas obras que são repertórios fundamentais sob o ponto de vista iconográfico, retórico e hermenêutico e das quais a mais famosa é sem dúvida a Iconologia de de Cesare Ripa (ca.1560-1625) ${ }^{35}$. Semelhantes repertórios foram elaborados e obtiveram larga fortuna, porque existia a consciência de que o discurso da poesia era difícil e obscuro, ocultando verdades profundas sob o véu de mistérios sagrados e vedando assim o seu conhecimento aos leitores vulgares que não estavam iniciados nos saberes indispensáveis à compreensão desses mistérios. A alegoria era o cerne da dificuldade e da obscuridade da poesia e por isso os tratados de alegorese tiveram assinalado êxito ${ }^{36}$.

A relação da alegoria com a ironia e com a dissimulação, na acepção retórica destes termos, é particularmente importante e frequente, porque a alegoria é uma modalidade de escrita oblíqua, dúplice, em que os significados se sobrepóem e se escondem uns nas dobras dos outros, num processo espiralar invertido em que as máscaras e os disfarces não são apenas aparências e obstáculos que têm de ser removidos pelo intérprete, porque eles fazem parte integrante do próprio significado global a desvelar. "Pecho sin secreto es carta abierta», escreveu Gracián no Oráculo manual. Ora a alegoria, salvo nos casos da sua trivial convencionalidade e explicitude demótica, não é uma carta aberta $^{37}$. $\mathrm{O}$ intérprete, como o caçador do modelo cinegético de investigação atrás mencionado, tem de procurar no ocultamento, na dissimulação, no segredo do que se diz, escreve, desenha, pinta e modela, a presa de caça que origina e justifica o seu labor venatório.

${ }^{33}$ Sobre a distinção entre tota allegoria e permixta apertis allegoria, que remonta a Quintiliano (Institutio Oratoria, 8,6,47), cf. Heinrich Lausberg, Elementos de retórica literária. Tradução, prefácio e aditamentos de R. M. Rosado Fernandes. Lisboa: Fundação Calouste Gulbenkian, 1972², p. 249.

${ }^{34}$ Um elucidativo exemplo é o nome das personagens Critilo e Andrenio de El Criticón de Gracián. Cf. Luis F. Avilés, Lenguaje y crisis: Las alegorías de «El Criticón». Caracas-Madrid: Editorial Fundamentos, 1998, pp. 175 ss.

${ }^{35}$ A Iconologia de Cesare Ripa foi reeditada numerosas vezes até finais do século XVIII, tendo sido uma das obras mais influentes nas artes plásticas e na literatura europeias desde o Maneirismo até ao dealbar do Romantismo, tanto no plano da criação como no plano da hermenêutica. Há várias ediçóes recentes, em diversas línguas,da Iconologia de Ripa (por ex., a edição da Iconologia publicada em Milano: Editori Associati, 1992, ou a tradução francesa publicada em Paris - Lille: Éditions aux Amateurs de Livres - Bibliothèque Interuniversitaire de Lille, 1989).

${ }^{36}$ Como sublinha Lina Bolzoni, muitas vezes as leituras alegoréticas, incidindo sobre textos alegóricos já de si difíceis e obscuros, convertem-se elas próprias em exercícios complexos e desenfreados de alegorese (cf. Lina Bolzoni, «L'allegoria, o la creazione dell'oscurità». L'Asino d'oro, 3, 1991, especialmente p. 55). Tal como Rabelais denunciou, como se disse, a proliferação de abstrusos sentidos alegóricos desentranhados em Homero por imaginosos comentadores, assim Montaigne ridicularizou nos Essais as pretensóes da alegorese, embora, como alegoricamente diz Antoine Compagnon no seu belo livro Chat en poche. Montaigne et l'allégorie (Paris: Éditions du Seuil, 1993), nos argumentos e contra-argumentos de Montaigne, a alegoria acabe por entrar pela janela...

${ }^{37}$ Há alegorias que, pela sua reiterada utilização, se convertem em lugares-comuns na cultura de uma comunidade, num determinado tempo histórico. Quando ocorrem transformaçóes histórico-culturais, sociais e estéticas, que modificam a enciclopédia do leitor e do espectador comuns, a alegoria que fora semanticamente transparente pode tornar-se opaca, requerendo a sua leitura uma informação especializada. 
6.

O Neoclassicismo setecentista, com o seu racionalismo e os seus princípios estéticos da mimese e da verosimilhança, não podia compreender as raízes e as motivaçóes mais profundas, dissimuladas e até herméticas da alegoria. Enquanto enigma, esta entrava em conflito com as exigências de clareza do pensamento e de transparência semântica advogadas pela estética neoclássica e por isso La Harpe considerava que a alegoria se encontrava idealmente definida neste verso de Lemierre, um poeta hoje esquecido: L'allégorie habite un palais diaphane ${ }^{38}$. Em consonância com este entendimento, Diderot aconselha os artistas a utilizarem sobriamente a alegoria e sublinha a natureza fria e obscura deste recurso retórico: «N'inventez de nouveaux personnages allégoriques qu'avec sobriété, sous peine d'être énigmatique. [...] L'allégorie, rarement sublime, est presque toujours froide e obscure» ${ }^{39}$.

Ora bem, na sua dinâmica dupla, a alegoria pode privilegiar a tendência para criar significados convencionais, transparentes e facilmente apreensíveis por um vasto número de receptores. A literatura neoclássica, com as suas preocupaçóes fortemente didácticas, moralistas e epidícticas, cultivou de modo explícito e reiterado a alegoria com significação evidente, multiplicando as personificaçóes de entidades abstractas, de sentimentos, de atributos morais, etc., e desenvolvendo, a partir de significados literais bem conhecidos, significados alegóricos de fácil compreensão que confluem numa conclusão suasoriamente didáctica e moral. Leia-se, como exemplo ilustrativo deste modelo de alegoria neoclássica, o poema de Bocage intitulado "Alegórico moral: o quadro da vida humana». O título apresenta logo ao leitor o percurso semântico de alegoria desenvolvida no texto - a alegoria do navio que, governado por inexperta mão, enfrenta uma furiosa tempestade marítima e nela soçobra -, confluindo depois os significados alegóricos parciais disseminados no poema na lição didáctico-moral condensada na derradeira estrofe:

Oh ente racional! Oh ente frágil!

Escravo das paixões, que te arrebatam!

Olhos sizudos neste quadro emprega:

Eis o quadro da vida. ${ }^{40}$

O alegorismo da literatura e da arte neoclássicas degradou-se na trivialização e no artificialismo e por isso o narrador de Jacques le Fataliste, no seu colóquio metaficcional

${ }^{38}$ Cf. Pierre Fontanier, Les figures du discours. Paris: Flammarion, 1968, p. 114.

${ }^{39}$ Diderot, «Pensées détachées sur la peinture, la sculpture et la poésie», Euvres esthétiques. Paris: Garnier, 1968, p. 766. Paul Vernière, responsável por esta excelente edição, regista em nota que esta crítica da alegoria procede da obra Réflexions critiques sur la poésie et la peinture (Paris, 1715) do Pe Du Bos. Um crítico, historiador e teorizador da arte tão influente como Winckelmann, na sua obra Da alegoria, publicada em 1766, censurou igualmente as alegorias obscuras e complicadas: «Uma alegoria simples assemelha-se ao ouro puro e a prova da sua bondade manifesta-se quando explica muitas coisas com poucos meios» (apud Patrick Labarthe, op. cit, p. 285). Winckelmann, ao advogar a simplicidade e a clareza da alegoria, procurava defender esta figura retórica de críticas como as do Pe Du Bos.

${ }^{40}$ Cf. Antologia da poesia portuguesa (séc. XII a séc. XX). Introdução, selecção e notas de Alexandre Pinheiro Torres. Porto: Lello \& Irmão, 1977, vol. II (sécs. XVII a XX), p. 663. 
com o leitor, desqualifica ironicamente a alegoria: «Vous allez dire que je m'amuse, et que, ne sachant plus que faire de mes voyageurs, je me jette dans l'allégorie, la ressource ordinaire des esprits stériles ${ }^{41}$. Diderot, com a sua sensibilidade moderna tão receptiva aos poderes criadores da imaginação e do génio, antecipava com esta desqualificação da alegoria novos horizontes da teoria estética e da prática poética. Esses horizontes abriramse, desde finais do século XVIII, com o idealismo e o romantismo germânicos.

\section{7.}

Com efeito, no declinar do século XVIII, apareceu com frequência e relevância crescentes em obras de estética, de poética, de crítica literária e de história de arte, uma palavra plurissecular que irá adquirir novos e fundamentais significados na estética do Romantismo alemão e do Romantismo em geral: a palavra símbolo. Trata-se de uma palavra utilizada já por um estóico como Crisipo e por um neoplatónico como Dionísio Areopagita, oriunda do domínio da religião, da teologia e da metafísica, mas alheia como termo técnico à área da retórica, como comprova a sua ausência dos dois últimos grandes tratados da retórica europeia - o Traité des tropes (1730) de Du Marsais e Les figures du discours (1830) de Fontanier ${ }^{42}$.

Kant, no famoso $\$ 59$ da Crítica da Faculdade do Juizo, caracterizou o símbolo como «uma espécie do modo de representação intuitivo» que contém "apresentaçôes indirectas do conceito». "A nossa linguagem», prossegue Kant, «está repleta de semelhantes exposições indirectas segundo uma analogia pela qual a expressão não contém o esquema próprio para o conceito, mas simplesmente um símbolo para a reflexão» ${ }^{43}$. Kant formula neste passo da sua obra uma contribuiçáo fundamental para a compreensão da ontologia e da epistemologia da obra de arte: o símbolo é um modo de representação em que, mediante uma analogia, a faculdade do juízo constrói uma intuição sensível do objecto e sobre esta e mediante esta exerce a reflexão que conduz ao conhecimento do mundo, do homem e de Deus. A intuição sensível do símbolo, na qual confluem a imaginação, a sensibilidade e o intelecto, torna possível um conhecimento poliédrico, e não redutoramente racional, da realidade fenoménica.

${ }^{41}$ Denis Diderot, Jacques le Fataliste et son maître. Paris: Garnier-Flammarion, 1970, p. 46.

${ }^{42}$ Veja-se, a propósito, Christian Vandendorpe, «Allégorie et interprétation», Poétique, 117 (1999), pp. 82-83. $\mathrm{O}$ autor sublinha que só após a consagraçáo romântica da palavra é que alguns dicionários lhe reconheceram o estatuto de figura retórica, atribuindo-lhe algumas características da alegoria. Na retórica contemporânea, verifica-se uma iniludível divisão doutrinária: enquanto autores, por exemplo, como H. Lausberg e H.F. Plett dão acolhida, de modo reticente, ao termo símbolo, outros autores como o Groupe $\mu$, Tomás Albaladejo, Armando Plebe e Pietro Emanuele ignoram-no.

${ }^{43}$ Immanuel Kant, Crítica da Faculdade do Juizo. Introdução de António Marques. Tradução e notas de António Marques e Valério Rohden. Lisboa: Imprensa Nacional-Casa da Moeda, 1988, pp. 261 e 262. Gadamer considera esta noção de (re)-presentação (Darstellung) simbólica "como uma das aquisiçôes mais admiráveis do pensamento kantiano" (cf. Hans-Georg Gadamer, Vérité et méthode. Édition intégrale [...]. Paris: Éditions du Seuil, 1996, p. 92). Gadamer apresenta nas pp. 87 e ss. e 158 e ss. do seu opus magnum uma análise admirável dos conceitos de simbolo e de alegoria. 
O símbolo kantiano condivide com a alegoria a translação do significado de um domínio para outro, mas enquanto a alegoria em Kant, como se depreende do $₫ 48$ da Crítica da Faculdade do Juizo, se funda numa interpretação elaborada pela razão, o símbolo, na sua criação e na sua leitura, convoca a intuição, a sensibilidade, a imaginaçáo e o intelecto. Kant não contrapôs formal e directamente o símbolo à alegoria, mas abriu a porta para a formulação e para o desenvolvimento dessa antinomia.

Gœethe reflectiu e escreveu, ao longo de muitos anos, sobre a distinção entre símbolo e alegoria e foi um dos grandes responsáveis, juntamente com Schelling, A.W. Schlegel e Coleridge, pela valorização estética do símbolo e pela correlativa desqualificação da alegoria, opondo a modernidade estética, a plurissignificaçáo, a capacidade de revelação do universal e do infinito do símbolo - forma orgânica, intransitiva, autotélica, na qual se manifesta a dinâmica criadora da imaginaçáo e que se dirige tanto à percepçáo como à intelecção -, à natureza antiquada, artificiosa, esquemática e abstractizante da alegoria, forma mecânica, transitiva e heterotélica que se dirige tâo-só à intelecção.

Num curto texto manuscrito datado de 1797, intitulado «Os objectos das artes plásticas», publicado postumamente, Gœthe desvalorizou as obras alegóricas, «que brilham pela razão, o espírito (Witz) e a galanteria», porque elas destroem o interesse pela representaçáo em si mesma e conduzem o espírito (Geist) como que a fechar-se em si próprio. Em seguida, Gœethe formula, pela primeira vez, uma explícita contraposição entre a alegoria e o símbolo: «A alegoria e o símbolo distinguem-se pelo facto de que o segundo designa indirectamente, ao passo que a primeira designa directamente» ${ }^{44}$. Gothe retoma a distinção entre alegoria e símbolo em diversos textos coligidos nas suas Máximas e reflexóes, desvalorizando sempre a alegoria e exaltando em contrapartida as capacidades representativas e cognitivas do símbolo: «Há uma grande diferença entre o poeta buscar o Particular em direcção ao Universal e contemplar o Universal no Particular. A primeira maneira dá origem à alegoria, em que o Particular apenas vale como exemplo, como jogo demonstrativo (Beispiel). A outra maneira, porém, é propriamente a natureza da poesia: ela exprime um Particular sem pensar no Universal ou aludir a ele. E assim é que quem capta vivencialmente este Particular sem pensar no Universal recebe com ele o Universal sem se dar conta disso, ou só mais tarde» ${ }^{45}$. Nas máximas 1112 e 1113 , Gœthe analisa com minúcia as relaçóes, na alegoria e no símbolo, do fenómeno com o conceito ou a ideia e a imagem, realçando a fulguração semântica inexaurível do símbolo: «A alegoria transforma o fenómeno num conceito e o conceito numa imagem, mas só na medida em que o conceito se deixa limitar e plenamente conter e agarrar pela imagem e nela esteja plenamente expresso. O simbólico transpóe o fenómeno em Ideia e a Ideia em imagem, de tal modo que a Ideia permanece na imagem sempre infinitamente actuante e inalcançável e mesmo que expressa em todas as línguas - se mantém inexprimível» ${ }^{46}$. O symbolon, o sinal de reconhecimento em que a partir de duas metades se refaz a unidade, é a revelação viva e

${ }^{44}$ J.W. Gœthe, Écrits sur l'art. Textes choisis, traduits et annotés par Jean-Marie Schaeffer. Paris: Klincksieck, 1983, p. 91.

${ }^{45}$ Gœthe, Máximas e reflexões. Tradução de Afonso Teixeira da Mota. Lisboa: Guimarães Editores, 20014 , p. 71 (máxima 279).

${ }^{46}$ Gothe, op. cit., pp. 213-214. 
instantânea do inexplorável, como se lê na máxima no 314, isto é, constitui uma forma orgânica que desvela sentidos da esfera do mistério e do religioso.

A inscrição do símbolo, com o significado originário, etimológico, de symbolon, na área da religião e da teologia encontra-se explicitamente formulada na antinomia entre alegoria e símbolo que Coleridge estabeleceu num passo famoso em The Statesman's Manual: «Now an Allegory is but a translation of abstract notions into a picture language which is itself nothing but an abstraction from objects of the senses [...] On the

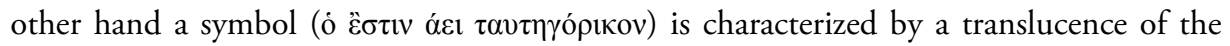
Special in the Individual or of the General in the Especial or of the Universal in the General. Above all by the translucence of the Eternal through and in the Temporal ${ }^{47}$. A palavra translucence, que significa a acção de brilhar através de algo, demonstra como o conceito de símbolo em Coleridge é indissociável da metafísica da luz e do pensamento neoplatónico: o símbolo revela a verdade do Eterno na contingência do Temporal. O símbolo, sublinha Coleridge, não é uma metáfora, uma alegoria ou qualquer outra figura de linguagem, mas uma verdadeira e essencial parte da natureza - natureza que é criatura e manifestação de Deus ${ }^{48}$. O poeta, graças aos poderes da imaginaçáo, coaduna no símbolo o transcendente e o terreno. Assim, a poética romântica do símbolo é indissociável de uma ontologia e de uma teologia ${ }^{49}$.

\section{8.}

A concepção romântico-idealista de símbolo exerceu uma tão profunda influência na estética oitocentista e novecentista que a alegoria passou a ser generalizadamente considerada como um processo retórico-estilístico anacrónico, artificial, mecânico e falseador de representação estética. O conceito romântico de símbolo reintegrava o homem e a história na transcendência, desvelava "o sentido universal infinito», convertia a arte e em especial a poesia em formas supremas de conhecimento do absoluto e impedia, mercê da sua

\footnotetext{
${ }^{47}$ Samuel Taylor Coleridge, "The Statesman's Manual», Lay Sermons. Edited by R.J. White. LondonPrinceton: Routledge \& Kegan Paul - Princeton University Press, $1993^{2}$, p. 30. O termo «tautegórico» opõe-se a «alegórico» e foi utilizado, por exemplo, por Schelling a propósito da mitologia, a qual, segundo o filósofo, "não é alegórica; é tautegórica. Para a mitologia, os deuses são seres que realmente existem; [...] significam só o que são" (apud Jon Whitman, ed., op. cit., p. 293).

${ }^{48}$ Id., op. cit., p. 79.

${ }^{49}$ Curiosamente, Friedrich Schlegel utiliza o termo «alegoria» e não o termo «símbolo» no seu Diálogo sobre a Poesia (1800), quando uma personagem da obra afirma: «Por outras palavras: toda a beleza é alegoria. O mais elevado, porque é inefável, só pode ser dito alegoricamente» (Friedrich Schlegel, Poesía e filosofía. Versión española de Diego Sánchez Meca y Anabel Rábade Obradó. Madrid: Alianza Editorial, 1994, p. 127). O Gespräch über die Poesie foi publicado em 1800 na revista Athenäum. Quando Schlegel reviu o texto do Diálogo para publicação nas suas Sämtliche Werke, substituiu o termo "alegoria» pelo termo «símbolo». Paul de Man, no seu ensaio "The rhetoric of temporality» considerou esta substituição "um acto de ontológica má-fé» e uma "mistificaçấo" (cf. Blindness and insight. Essays in the rhetoric of contemporary criticism. London: Methuen, 1983², p. 211). Penso que Paul de Man, na esteira de uma longa tradiçấo crítica adversa a Friedrich Schlegel, formulou uma censura injusta. O próprio Paul de Man reconhece a influência que terão exercido em Schlegel, depois de 1800, autores como Creuzer e Schelling.
} 
dinâmica originariamente orgânica, a "disjunção das faculdades» do homem. As poéticas do Simbolismo e do Modernismo e o pensamento estético, poetológico e crítico de Benedetto Croce e dos grandes representantes do new criticism, desde Susanne K. Langer até Cleanth Brooks, W.K.Wimsatt e Murray Krieger, desenvolveram e aprofundaram este legado romântico. Até um pensador marxista como Georg Lukács defendeu o conceito gœthiano de símbolo em diversos passos da sua obra, em especial no capítulo «Alegoria e símbolo» da sua Estética, transferindo para o plano de uma teologia secularizada a originária inscrição do símbolo romântico na esfera da teologia religiosa ${ }^{50}$.

Um elucidativo exemplo da desvalorizaçáo idealista da alegoria encontra-se em Jorge Luís Borges, que repetidas vezes manifestou hostilidade e azedume em relação à poética e à arte alegóricas. No breve ensaio intitulado «De las alegorías a las novelas», coligido em Otras Inquisiciones (1952), depois de citar a condenaçáo da poesia formulada por Croce na obra La poesia (1936) e depois de mencionar a vindicação da alegoria efectuada por G.K. Chesterton, escreve Borges: "No sé muy bien cuál de los eminentes contradictores tiene razón; sé que el arte alegórico pareció alguna vez encantador (el laberíntico Roman de la Rose, que perdura en doscientos manuscritos, consta de veintiquatro mil versos) y ahora es intolerable. Sentimos que, además de intolerable, es estúpido y frívolo»" ${ }^{51}$.

Poder-se-ia deduzir das análises precedentes que, após a celebração romântica do símbolo, a alegoria teria sofrido um destino similar ao de uma espécie biológica em extinção. Seria uma dedução apressada e errónea, pois que a desvalorizaçáo generalizada da alegoria não equivaleu - não podia equivaler - ao desaparecimento de um fenómeno retórico e hermenêutico secularmente relevante na cultura europeia e que corresponde a estratégias expressivas e interpretativas inelidíveis do espírito humano. $\mathrm{Na}$ história moderna da alegoria, o que avulta, ao lado da sua desvalorização pós-romântica, é a sua reivenção surpreendentemente como tropo da modernidade, isto é, como tropo de uma modernidade poética que representa a melancolia incurável, a obsolescência intrínseca, a venalidade e a mentira da modernidade social.

A reabilitação e a reinvenção da alegoria, quer no plano da reflexão poetológica, quer no plano da criação poética, ficou a dever-se exactamente ao poeta por excelência da modernidade poética europeia - Charles Baudelaire. A presença e a relevância da alegoria na sua obra poética e crítica têm sido objecto de iluminadores estudos. Utilizando termos e conceitos predilectos de Walter Benjamin, direi que a reinvenção da alegoria em

50 Terry Eagleton sublinha justamente que a estética marxista foi fundamentalmente uma amálgama ambígua de idealismo e de materialismo e que, no fim do século XIX e nas primeiras décadas do século XX, a crítica marxista se constituiu com base no positivismo sociologista e no idealismo neo-kantiano (cf. Terry Eagleton, Walter Benjamin or towards a revolutionary criticism. London: Verso, 1981, pp. 82-83). Relembre-se que Lukács teve uma inicial formação filosófica e em particular estética de matriz idealista e sobretudo hegeliana, como testemunha a sua Teoria do romance (1916).

${ }^{51}$ Jorge Luis Borges, Prosa Completa. Barcelona: Brugera, 1980, pp. 268-269. Cuesta Abad anota, com razão e finura, que estas palavras de Borges são surpreendentes e que deverão ser lidas como uma alegoria irónica: «no puede sino sorprender la lectura de unas tajantes palabras de desprecio artístico hacia lo alegórico en un autor que escribe alegoricamente, que incluso concibe e imagina el mundo alegoricamente. Por tanto, será preciso comprender los severos juicios borgeanos como si fueram al mismo tiempo una alegoría de tipo irónico: su crítica rotunda constituye más bien una dissimulatio que un anátema estético" (José M. Cuesta Abad, Ficciones de una crisis. Poética e interpretación en Borges. Madrid: Gredos, 1955, p. 195). 
Baudelaire tem uma pré-história em Edgar A. Poe e uma pós-história no próprio Benjamin e em Paul de $\mathrm{Man}^{52}$. A primeira estrofe da parte II do poema de Baudelaire Le Cygne condensa essa pós-história em Walter Benjamin:

Paris change! mais rien dans ma mélancolie

N'a bougé! palais neufs, échafaudages, blocs,

Vieux faubourgs, tout pour moi devient allégorie,

Et mes chers souvenirs sont plus lourds que des rocs.

9.

Após ter escrito, em 1922, o grande ensaio sobre as Afinidades electivas de Gœthe, que seria publicado em 1924-25, Walter Benjamin, que tinha realizado o doutoramento na Universidade de Berna, em 1919, com a tese $O$ conceito de critica de arte no Romantismo alemão, decidiu obter a venia legendi (permissão ou licença para ensinar), mediante o exame de Habilitation numa Universidade alemá, a fim de prosseguir uma carreira académica. Optou pela Universidade de Frankfurt am Main, de criação recente, e escolheu como orientador o professor catedrático Franz Schultz, que lhe propôs como tema o Trauerspiel (o drama trágico, a representação lutuosa) do período barroco, matéria até então votada ao esquecimento. Walter Benjamin trabalhou na dissertação entre 1923 e 1925 e, ao apresentar a Habilitationsschrift ao orientador e aos seus colaboradores do Departamento de Língua e Literatura Alemãs, sofreu o choque de ver a tese rejeitada. A obra viria a ser publicada, em 1928, em Berlim, sob o título de Ursprung des deutschen Trauerspiels. O silêncio, exceptuando as apreciaçóes laudativas de Hofmannsthal e de Adorno, abateu-se durante longos anos sobre esta obra que, só após algumas décadas, se tornou conhecida como um estudo profundamente inovador para o conhecimento do Barroco e como o texto fundamental para a reconceptualização da poética alegórica.

Walter Benjamin inicia a obra com um longo e complexo «Prólogo Epistemológicocrítico», por vezes pouco claro e de compreensão difícil - Benjamin aconselhará mesmo alguns amigos a lerem o prólogo depois da leitura do livro -, no qual expóe ideias e desen-

\footnotetext{
${ }^{52} \mathrm{O}$ estudo fundamental sobre a alegoria em Baudelaire é a já citada obra de Patrick Labarthe, Baudelaire et la tradition de l'allégorie. Veja-se também Hans Robert Jauss, "El recurso de Baudelaire a la alegoría», Las transformaciones de lo moderno. Estudios sobre las etapas de la modernidad estética. Madrid: Visor, 1995, pp. 143159; id., "On the question of the 'structural unity' of older and modern lyric poetry (Théophile de Viau: Ode III; Baudelaire: Le Cygne)", Aesthetic experience and literary hermeneutics. Minneapolis: University of Minnesota Press, 1982. Numa perspectiva neo-marxista, é importante a obra de Romano Luperini, L'allegoria del moderno. Saggi sull'allegorismo come forma artistica del moderno e come metodo di conoscenza. Roma: Editori Riuniti, 1990. Sobre os conceitos de pré-história e pós-história em Benjamin, veja-se John McCole, Walter Benjamin and the antinomies of tradition. Ithaca-London: Cornell University Press, 1993, especialmente pp. 295 ss. Veja-se também Michael W. Jennings, Dialectical images. Walter Benjamin's theory of literary criticism. Ithaca-London: Cornell University Press, 1987, cap. 1: «Benjamin's Baudelaire: The shape of Benjamin’s mature criticism».
} 
volve reflexóes de crucial interesse para o entendimento da sua tese e, mais latamente, para a elaboração de uma teoria dos géneros literários e de uma teoria dos períodos literários ${ }^{53}$.

Julgo particularmente importante a sua crítica do método indutivo praticado pela análise histórico-literária, centrada na multiplicidade dos fenómenos e na contingência do processo histórico e fundada na acumulação e no "empilhamento dos factos» (p. 26), como se os dados quantitativos pudessem proporcionar a inteligibilidade dos fenómenos históricos, culturais e estéticos. Em contrapartida, Walter Benjamin formula a proposta da existência das «ideias constitutivas» - os universalia in re -, utilizando uma expressão empregue por Konrad Burdach, conhecido historiador da Reforma, do Renascimento e do Humanismo. As ideias de Benjamin têm uma inequívoca genealogia platónica - Platão é a auctoritas filosófica do «Prólogo Epistemológico-crítico» e Benjamin refere-se mesmo a «uma teoria da ciência platonicamente orientada para a representação das essências» (p. 27) - e náo se identificam com os conceitos, que procedem à análise dos fenómenos nos seus elementos constituintes. As ideias incluem e absorvem os fenómenos do mundo empírico graças à mediaçáo dos conceitos. Numa analogia que se tornou famosa, Benjamin concebe as ideias como constelaçóes: "As ideias relacionam-se com as coisas como as constelaçóes com as estrelas. Isto significa desde logo que elas não são, nem os conceitos, nem as leis das coisas» (p. 20). Estas constelaçóes são eternas e nelas se inscrevem, «simultaneamente dispersos e salvos», os fenómenos, ou melhor, os elementos dos fenómenos que os conceitos analiticamente destacam e circunscrevem.

A eternidade das ideias articula-se, porém, com a historicidade das formas e manifestase diversamente no transcurso da história, cabendo à interpretação desvelar esta articulação. Nesta perspectiva, o conceito benjaminiano da ideia tem afinidades evidentes com o conceito de eón formulado por Eugenio d'Ors no seu livro Lo barroco ${ }^{54}$. A ideia, no seu ser essencial, comanda o desenvolvimento, na sua pré-história, na sua história e na sua póshistória, da vida das formas e das obras. Esta dinâmica, em que eternidade e história se conjugam, configura a ideia como totalidade e como uma entidade monadológica: «A ideia é uma mónada. O ser que nela penetra com a sua pré- e pós-história mostra, oculta na sua própria, a figura abreviada e ensombrada do restante mundo das ideias, tal como nas mónadas do Discurso sobre a Metafísica de 1686: em cada uma delas estáo indistintamente presentes todas as demais. A ideia é uma mónada - nela repousa, pré-estabelecida, a representação dos fenómenos como sua interpretação objectiva» (p. 34) (5) $^{55}$.

${ }^{53}$ Utilizo a tradução portuguesa, da autoria de João Barrento, mencionada atrás na nota $\mathrm{n}^{\circ} 16$. Seguidamente, no corpo do texto sinalizo as citaçóes apenas com o número da página.

${ }^{54} \mathrm{O}$ termo e o conceito neoplatónicos de eón, retomados por Eugenio d'Ors, referem-se a uma categoria de carácter metafísico que tem um desenvolvimento inscrito no tempo histórico: «en el «eón», lo permanente tiene una historia, la eternidad conoce vicisitudes» (Eugenio d'Ors, Lo barroco. Madrid: Tecnos-Alianza Editorial, 2002, p. 67). O barroco é concebido por d'Ors como um eón, tal como o classicismo. Recorde-se que Eugénio d'Ors expôs a sua teoria do barroco como um eón na célebre «Década» da Abadia de Pontigny realizada em 1931 e que em 1935 foi publicado em Paris (Gallimard) o seu livro Du Baroque. Não encontro qualquer rasto de uma possível influência de Benjamin no pensamento de Eugenio d'Ors. As afinidades teóricas, a este respeito, entre os dois autores procedem decerto de doutrinas histórico-filosóficas e estéticas com largo curso nos finais do século XIX e princípios do século XX e cuja principal matriz é o pensamento de Nietzsche.

${ }^{55}$ Como esclarece em nota João Barrento, Benjamin refere-se ao Discours de Métaphysique de Leibniz, escrito em 1686, mas apenas editado em 1846. A teoria monadológica de Leibniz exerceu um poderoso fascínio em 
$\mathrm{Na}$ sua dissertação de Habilitation, Walter Benjamin concedeu um lugar central e uma atenção particular a duas ideias constitutivas: a ideia de drama trágico (Trauerspiel), que se inscreve no plano das entidades genológicas, e a ideia de Barroco, uma entidade periodológica na qual se exprime e representa uma «vontade artística» (Kunstwollen) diversa da do Renascimento e do Classicismo setecentista ${ }^{56}$.

Ao repensar, segundo as suas palavras, "os grandes objectos da filologia do Barroco», procurando avançar na sua fundamentação filosófica, Walter Benjamin fixou a sua atenção, como ponto de partida e como fio condutor, no fenómeno alegórico, adoptando no fundo, embora com reservas e algumas contestaçóes, a tese formulada por Herbert Cysarz na obra Deutsche Barockdichtung (Leipzig, 1924), segundo a qual a alegorese é «a lei estilística dominante, em particular do apogeu do Barroco», e que seria a técnica da alegoria, e não a arte do símbolo, a característica própria da representação e do estilo do Barroco.

Benjamin afirma peremptoriamente que a filosofia da arte, havia mais de um século, «[era] dominada por um usurpador que chegou ao poder no caos gerado pelo Romantismo» (p. 173). Este «usurpador» é o símbolo, oriundo do campo teológico, que a estética teosófica dos românticos concebeu como a representação da unidade do objecto sensível e do plano supra-sensível. Benjamin denuncia a apologia do símbolo que, desde os finais do século XVIII, foi levado a cabo por vários autores, a começar por Gothe, e a correlata desvalorização da alegoria, embora reconheça que no Classicismo não surgiu uma satisfatória e legitimadora teoria da figura alegórica.

É exactamente uma nova teoria da alegoria que Walter Benjamin fundamenta e elabora, a partir de reflexóes sobre o símbolo e a alegoria e as suas relaçóes com o tempo desenvolvidas por autores do período romântico como Friedrich Creuzer e Josef Görres, expressivamente citados na Origem do drama trágico alemão: o símbolo é uma totalidade momentânea, é uma fulguração adunativa do sensível e do supra-sensível, uma espécie de experiência mística individual ancorada no absoluto, ao passo que a alegoria representa as ideias no fluir do tempo, na sucessão histórica, por conseguinte no domínio do contingente, da transiência e da morte. Benjamin formula assim as conclusóes sobre a relação do símbolo e da alegoria com a temporalidade: «A relação entre símbolo e alegoria pode ser fixada com a precisão de uma fórmula remetendo-a para a decisiva categoria do tempo, que a grande

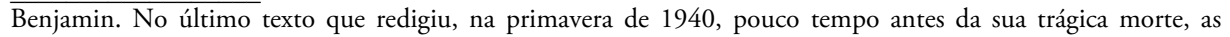
arquifamosas "Teses de filosofia da história», Walter Benjamin formula a XVII tese em torno do conceito de mónada, afirmando que o historiador materialista só se confronta com um objecto histórico quando este se lhe apresenta como mónada (cf. Walter Benjamin, Angelus Novus. Saggi e frammenti. Torino: Einaudi, 1962, p. 82). É a mónada, na sua mencionada dinâmica de eternidade e de contingência histórica, que permite delimitar e destacar uma dada época no curso homogéneo da história. Esta tese XVII demonstra bem a relevância da teoria monadológica das ideias na concepçáo benjaminiana dos períodos literários. A aproximação que Benjamin estabelece entre o Barroco e o Expressionismo inscreve-se na dinâmica das ideias monadológicas.

$56 \mathrm{O}$ conceito de "vontade artística» (Kunstwollen) foi elaborado pelo historiador da arte Aloïs Riegl sobretudo na sua obra $A$ indústria artística da fase tardia do Império Romano (Die spätrömische Kunstindustrie) (1918) - obra que Walter Benjamin admirava e cita na Origem do drama trágico alemáo. A Kunstwollen de Riegl configura um fenómeno colectivo de energia criadora e expressiva que co-envolve a religião, a filosofia, a ciência, a política, o direito, etc., e que conduz o mesmo povo, no mesmo desenvolver cânones e padrôes artísticos relativamente homogéneos, que se manifestam em cada obra de arte (e por isso as concepçóes estéticas de Benjamin desvalorizam o criador individual, situando-se no pólo oposto ao da estética de Benedetto Croce). 
intuição romântica desses pensadores [Creuzer e Görres] trouxe para este domínio da semiótica. Enquanto no símbolo, com a transfiguração da decadência, o rosto transfigurado da natureza se revela fugazmente na luz da redenção, na alegoria o observador tem diante de si a facies hippocratica da história como paisagem primordial petrificada. A história, com tudo aquilo que desde o início tem em si de extemporâneo, de sofrimento e de malogro, ganha expressão na imagem de um rosto - melhor, de uma caveira» (p. 180). A caveira é a figura extrema, enigmática e dolorosa, da transitoriedade da vida humana e da miséria mortal dos indivíduos, das sociedades e das civilizaçôes e da própria natureza. A morte está inscrita em tudo quanto existe, não havendo qualquer Arcádia que escape ao seu império, e encontra-se substancialmente associada à representação alegórica: «Está aqui o cerne da contemplação do tipo alegórico, da exposição barroca e mundana da história como via crucis do mundo: significativa, ela é-o apenas nas estaçóes da sua decadência. Quanto maior a significação, maior a sujeição à morte, porque é a morte que cava mais profundamente a tortuosa linha de demarcação entre a physis e a significação. Mas a natureza, se desde sempre está sujeita à morte, é também desde sempre alegórica. A significação e a morte amadureceram juntas no decurso do processo histórico, do mesmo modo que se interpenetram, como sementes, na condição criatural, pecaminosa e fora da Graça» (pp. 180-181).

Após o Classicismo do Renascimento, ao qual, observa Benjamin, estava vedado, pela sua própria essência, «apreender na physis sensível e bela o que nela havia de náo-livre, de imperfeição, de fragmentário» (p.191), no Barroco a natureza e a história só são pensáveis como fragmento e como ruína, sendo a alegoria a expressão fragmentária e disseminativa dessas cenas de ruína: «As alegorias são, no reino dos pensamentos, o que as ruínas são no reino das coisas. Daqui vem o culto barroco da ruína» (p. 193).

Sob o efeito devastador dos conflitos religiosos e morais gerados pela Reforma e pela Contra-Reforma, das novas visóes do universo decorrentes das descobertas científicas, das guerras sucessivas, das pestes, das crises financeiras e económicas, estilhaçou-se irremediavelmente o sentido da totalidade e da harmonia cósmicas e da confiança no poder criativo do homem, proclamado, exaltado e levado à prática pelo Classicismo do Renascimento. As ruínas do Barroco são os fragmentos de um cosmos - palavra que em grego significa ordem, disciplina, organizaçáo - estilhaçado e as alegorias são os fragmentos que discursivamente representam esse mundo descentrado, decadente e infeliz e esse homem melancólico, sombriamente melancólico, aterrado e fascinado pelo vazio e pelo nada: «No campo da intuição alegórica a imagem é fragmento, runa» (p. 191). Runa, ruína, inscrição funérea, epitáfio, memória ou premoniçáo de caducidade e de morte ${ }^{57}$.

A leitura benjaminiana do Barroco e em particular da alegoria barroca é intencional e deliberadamente uma leitura que retrojecta sobre esse passado literário, artístico e cultural, a melancolia baudelairiana, oscilante entre o sentido do eterno e o sentido do transitório e do contingente, e a melancolia, o terror e a agonia da modernidade apocalíptica que foi o tempo da vida e da morte do próprio Walter Benjamin. A melancolia moderna, fruto

\footnotetext{
${ }^{57}$ Sobre os "tempos póstumos» do mundo e do homem barrocos e as suas representaçōes literárias e artísticas e as suas projecçôes e incidências religiosas, morais, antropológicas, sociais, etc., veja-se a riquíssima obra de Fernando R. de la Flor, Era melancólica. Figuras del imaginario barroco. S.l.: José J. de Olañeta, Editor - Universitat de les Illes Balears, 2007.
} 
inevitável da catástrofe do progresso burguês e capitalista, ilumina desoladamente a melancolia barroca e esta, por sua vez, possibilita entender aspectos capitais, ocultos ou ambíguos, do tempo presente. Esta relação entre o passado (das Gewesene) e o presente, o agora (Jetzt), configura uma imagem dialéctica que possibilita deter o curso do tempo histórico e, nessa pausa, proporciona o verdadeiro conhecimento histórico. A alegoria baudelairiana e a alegoria kafkiana como a alegoria barroca são a representação impiedosa do sentimento e da consciência da perda, da dissipação e da fragmentação ontológica do homem. Daí a modernidade do Barroco e, dialecticamente, o carácter barroco ou o substrato barroco de grande parte da literatura e da arte da modernidade ${ }^{58}$.

A visão benjaminiana da alegoria barroca iluminou com uma luz nova, cruel, desencantada e niilista, a cena do Barroco e do grande teatro do mundo nela representada. $\mathrm{O}$ anjo benjaminiano da história, o anjo novo das ruínas e do abismo, figurado na tese IX das "Teses de filosofia da história», sobrepóe-se, numa alegoria expressionista, ao anjo lúdico, risonho e erótico, de muita arte religiosa e profana do Barroco - um anjo que terá sido, em muitos casos, a alegoria exorcismadora da melancolia e do sofrimento saturniano do homem barroco. Analisada a esta nova luz, a poética da alegoria barroca ganhou em profundidade hermenêutica e em complexidade antropológica, no seu contraste com a poética do Classicismo renascentista e com a poética do símbolo do Romantismo, mas existe o risco de assim se deixarem na sombra e no esquecimento outras faces ou outras vertentes dessa poética.

A alegoria é conatural, por exemplo, ao pendor e ao gosto obsessivos do Barroco pela aparência e pela metamorfose. Retórica e hermeneuticamente, o texto parece veicular um significado, mas este significado transmuda-se noutro ou noutros, numa deriva em que o engenho, a agudeza e a imaginação descobrem ou inventam pontes, passagens, analogias, alusóes, contraposiçóes. $\mathrm{Na}$ alegoria, uma camada de significado esconde outra camada de significado, comunica com outra camada de significado, e por isso a alegoria gera continuamente a plurivalência e a ambiguidade semânticas que o Barroco cultivou e explorou intencional e deliciadamente, num exercício em que se conjugam o engenho, a subtileza de entendimento das palavras, das imagens e das coisas e um irreprimível pendor lúdico. Muitas vezes, esta deriva de sentidos, por dificuldades hermenêuticas originadas pelo léxico, pela sintaxe, por relaçóes intertextuais de árdua identificação, por referências mitológicas ou históricas insólitas, etc., torna-se obscura e até críptica. A totta allegoria, o alieniloquium, sem elementos indiciários bastantes de interpretação, adequam-se especialmente ao gosto barroco pelo segredo, pelo secreto, pelo hieroglífico e pelo enigmático.

$\mathrm{Na}$ raiz histórica da alegoria enquanto fenómeno hermenêutico, como ficou exposto, encontram-se razóes de ordem religiosa e de ordem moral, em especial associadas a ideais e valores educativos. Daí a dimensão fortemente pragmática da alegoria, como fenómeno retórico e como fenómeno hermenêutico, de modo a seduzir, a captar e a influenciar as

${ }^{58}$ Sobre a relação entre a melancolia e a alegoria, vide Max Pensky, Melancholy dialectics. Walter Benjamin and the play of mourning. Amherst: The University of Massachusetts Press, 1993; Ferrucio Masini, "Melancholia illa allegorica», Brecht e Benjamin. Bari: De Donato, 1977, pp. 113-131; Mauro Ponzi, Walter Benjamin e il moderno. Roma: Bulzoni Editore, 1993 (sobretudo os capítulos 6, 7 e 9); José Manuel Cuesta Abad, Juejos de duelo. La historia según Walter Benjamin. Madrid: Abada Editores, 2004, passim. 
emoçóes, os afectos, a vontade e o juízo dos seus destinatários e receptores. A literatura barroca, sobretudo aquela mais estreitamente impregnada dos ideais e valores da Contra-Reforma, encontrou na alegoria um poderoso recurso para ensinar, para exortar, para comover os coraçóes e para demover os espíritos, encaminhando-os para as vias da contrição e da penitência e para o porto da redenção. A alegoria barroca não se esgota na representação da facies hippocratica da história e da natureza: nas alegorias dos textos literários, nas alegorias inter-artísticas dos emblemas, das empresas e das divisas, nas alegorias da pintura e da escultura, circula muitas vezes uma extraordinária energia militante, ascética, mística e celebratória, que exalta a majestade e o esplendor de Deus na história do homem e nas coisas do mundo e que busca redimir o homem, apelando à sua conversão. As igrejas barrocas, por exemplo, são a jubilatória antevisão alegórica do Paraíso aos olhos deslumbrados dos fiéis.

A oratória do Pe António Vieira é um genial e, a meu ver, insuficientemente estudado exemplo da capacidade pragmática, fática, perlocutiva, da alegoria barroca. Estudar a oratória de Vieira em contraluz - não digo, sublinho, em sentido contrário - com a teoria de Walter Benjamin sobre a alegoria barroca conduziria a uma aventura hermenêutica fascinante. O Barroco tem "múltiplas moradas», no sentido evangélico e no sentido comparatista que a esta expressáo atribuiu o saudoso e, entre todos os comparatistas contemporâneos, insigne Claudio Guillén. Walter Benjamin, com a originalidade, o rigor e a fulguração da sua analítica filosófico-literária, iluminou de modo inovador algumas «moradas» do Barroco, mas deixou outras por visitar, examinar e interpretar.

10.

Adeus ao Barroco, Último olhar sobre o Barroco... Não estarei eu a enunciar, pela voz de outros, alegorias barrocas, sob cuja camada visível de significado digo e contemplo a facies hippocratica de uma biografia pessoal e a facies hippocratica do saber humanístico e das próprias humanidades? E não serão hoje as Faculdades de Letras alegorias barrocas benjaminianas, como unidades inorgânicas da Universidade em ruína, a cuja anatomia cruel procedeu Bill Readings no seu desolado livro The University in ruins? $\mathrm{O}$ anjo da história das "Teses de filosofia da história» tem aos seus pés um monte crescente de ruínas, é impelido para o futuro, de costas voltadas, por um vento furioso, e tem os olhos escancarados com horror fixos no passado. Serão as Faculdades de Letras casas assombradas pelo anjo da história de Walter Benjamin? 
Série

Documentos

Imprensa da Universidade de Coimbra

Coimbra University Press

2010

- U

C • 